\title{
Controlling of the two-spotted spider mite, Tetranychus urticae Koch on three melon cultivars
}

\author{
Awad Ali Abdallah \\ Agric. Zoology and Nematology Dept. Faculty of Agriculture, Al - Azhar University \\ Corresponding author: awadabdallah28@yahoo.com
}

\begin{abstract}
Two predatory species (Phytoseiulus persimilis Athias-Henriot and Amblyseius swirskii Athias-Henrio), one biochemical compound Abamectin (Vapcomic) and one chemical compound (Ortus) as well as a control treatment were used to evaluate their effect in reducing the population densities of the two spotted spider mite, Tetranychus urticae Koch on three different melon cultivars (Shahd, Ananas and Galia) at Behaira Governorate during 2014 season. The average reduction percentage of spider mite, $T$. urticae population was significantly different among the different treatments on each of the Shahd $\left(F_{3,36}=15.65 ; P<0.05\right)$, Ananas $\left(F_{3,36}=10.14 ; P\right.$ $<0.05)$ and Galia $\left(F_{3,36}=13.75 ; P<0.05\right.$; Table 2$)$. The results of the overall mean reduction percentage of the spider mite populations on the three melon cultivars by the specialist predatory mite; $P$. persimilis was significantly highest $(93.66 \%)$. Followed by the chemical compound Ortus and the biochemical control Vapcomic (79.07 and $75.94 \%$ respectively with no significant difference between them). While the generalist predatory mite, Amblyseius swirskii had the lowest significantly with the mean reduction percentage (56.93\%). The results also implied that the shahd cultivar was relatively much tolerance to the spider mite, T. urticae infestation (38.85 individual/leaf; Table 1) than another tested cultivar (Ananas 82.72 or Galia 70.87 individual). Therefore, it could be concluded that cultivating the Shahd cultivar is preferable than Ananas or Galia cultivar and using $P$. persimilis for controlling T. urticae was superior than using the other methods.
\end{abstract}

\section{Key words: Spider mite; Tetranychus urticae; biological, biochemical.chemical control, melon cultivars}

\section{Introduction}

Melons (Cucumis melo var. reticulatus) are members of the cucurbit (Family: Cucurbitaceae), which also include several warm season vegetables such as watermelon, squash and cucumber. Melons comprise a broad array of wild and cultivated genotypes. The most common name used for Cucumis melo L. is melon. Other names include sweet melon, round melon, muskmelon, casaba, cantaloupe and winter melon (Nayar and Singh, 1998). Melon is an important vegetable crop that is widely cultivated in South-East Asia, China, and East Africa as well as throughout the tropical and subtropical regions (Yadav et al., 1996). It is attacked by several phytophagous species that reduce its quality and quantity.

The two-spotted spider mite, Tetranychus urticae Koch is polyphagous and this mite probably the most important pest species in the family Tetranychidae (Hussey and Huffaker 1976). It is the economically most important pest of many horticultural and field crops and attacks more than 200 host plants. The spider mite, T. urticae is mainly damaging on vegetables, ornamentals and fruit trees (van de Vrie et al. 1972). Tetranychus urticae causes great economical loss to many crop species all over the world (Helle and Sabelis, 1985).

Use of pesticides provides a quick and sometimes effective solution of pest problems but on the other hand, it has created several other problems. The intensive use of insecticides and acaricides has led to resistance in many insect and mite species around the globe (Van Leeuwen et al., 2010). It has been recognized for many years that spider mites have a propensity to develop resistance to pesticides. Therefore, there has been an increasing interest in controlling spider mites by biological control agents.

Several species of natural enemies have been reported to prey on $T$. urticae and studies have been conducted in different countries to assess the effect and potential of natural enemies for controlling the pest without the use of pesticides (Garcia-Mari and Gonzalez-Zamora, 1999). The phytoseiid is one of the most efficient predatory species of phytophagous mites (McMurtry and Croft, 1997) and phytoseiid mite species can keep the spider mite population densities below economic thresholds (Schausberger, 1991).

The predatory mite, Amblyseius (Typhlodromips) swirskii Athias-Henrio (Acari: Phytoseiidae) is a generalist predator known to feed on other mites, whitefly, thrips, lepidopteran eggs and pollen (Swirski et al., 1967; McMurtry and Croft, 1997). Amblyseius swirskii is a recent addition to the beneficial assortment, developed and marketed by the Dutch producer of beneficial (van Houten et al., 2005). Amblyseius swirskii is a polyphagous predator capable of preying on a number of spider mites (Swirski et al., 1967).

The phytoseiid mite, Phytoseiulus persimilis (Acari: Phytoseiidae) is widely used in biological programmes throughout the world (Cho et al., 1995). This predatory mite is a specialist predator feeding 
on Tetranychus species Type I phytoseiid mite (McMurtry and Croft, 1997). Phytoseiulus persimilis is used as a biological control agent for tetranychids worldwide, especially in protected crops (McMurtry and Croft, 1997; Zhang, 2003).

The present study was carried out to control of the spider mite, T. urticae on three different melon cultivars (Shahd, Ananas and Galia) by using two predatory mite species, (P. persimilis and A. swriskii) and one biochemical compound by using Abamectin (Vapcomic) as well as one chemical compounds by using fenpyroximate (Ortus) to evaluate their effect in reducing the population densities of this pest.

\section{Materials and Methods}

Three melon cultivars (Shahd, Ananas and Galia) were cultivated to study the effect of three types of control agents, biological, biochemical and chemical, on the phytophagous mite, T. urticae by releasing two predatory mite species and spraying two compounds (Vapcomic and Ortus) at El-Behaira Governorate.

\section{Experimental design:}

Three different melons (Shahd, Ananas and Galia) were cultivated to study the effect of three types of control agents: biological (two predatory mite species), biochemical and chemical, on phytophagous mite, T. urticae. Soil was well prepared; the area was about $20 \mathrm{~m}$ long by $4 \mathrm{~m}$ wide. The area was divided into 15 replicates. Sowing the seeds of the three varieties in the nursery was on 26\1\2014 and transplanted date on $1 \backslash 3 \backslash 2014$.

The effect of each of the previously mentioned four treatments was compared to the control treatment for each cultivar: each treatment was replicated three times. The experimental design was complete randomized block. In order to study the population of phytophagous mite species, leaf samples were collected weekly, starting on 26/03/2014 until 04/06/2014.

\section{Sampling Procedure:}

In order to study the population of the phytophagous mite after treated by the three control agents, 20 leaves of each treatment were randomly collected from the three cultivars and placed directly into plastic separate bags and transported to the laboratory. All mite stages were counted using stereomicroscope, to evaluate the reduction percentage of the pest populations on the melon cultivars.

\section{Rearing of the predatory mites:}

The predatory mites, $P$. persimilis and $A$. swirskii were reared using methods modified from (McMurtry and Scriven, 1965): large plastic boxes $26 \times 15 \times 10 \mathrm{~cm}$ were used. Cotton pad was placed in the middle of each box, leaving a space provided with water as a barrier to prevent predatory mites from escaping. A sheet of plastic was placed on the cotton pad the same size of the pad. Excised bean leaves highly infested with $T$. urticae were provided every day as food source for the predatory mites and plastic boxes were kept in an incubator at $25 \pm 2{ }^{\circ} \mathrm{C}$.

\section{Mass rearing of the predatory mites:}

For mass rearing of the predatory mites: on kidney bean, Phaseolus vulgaris (L.) was served as host plant which reared in a small glasshouse divided into three isolated parts (a) clean bean plants, (b) clean plants at stage of 12 leaves infested with spider mite, T. urticae (c) bean plants infested of five gravid females of the predatory mites for every plant (ElSaiedy, 2003). Temperature in the glasshouse ranged from 18 to $25^{\circ} \mathrm{C}$ and relative humidity from $50-$ $60 \%$.

\section{Releasing of the predatory mites:}

The predatory mite species: $P$. persimilis and $A$. swirskii were released on $26^{\text {th }}$ of March as the population density of $T$. urticae build upon melon with rate 1:7 predatory mite/prey, respectively for one time. Samples were taken weekly. Tetranychus urticae stages were counted.

\section{Other control types:}

The chemical compound: fenpyroximate (ORTUS) was sprayed one time (on $26^{\text {th }}$ of March) at the rate of $50 \mathrm{~cm}^{3} / 100$ Liter water $+250 \mathrm{~cm}^{3}$ oil kaby.

The biochemical compound: Abamectin (VAPCOMIC) also was sprayed one time (on $26^{\text {th }}$ of March) at the rate of $40 \mathrm{~cm}^{3} / 100$ Liter water +250 $\mathrm{cm}^{3}$ oil kaby.

The reduction percentages of the average population number of phytophagous species were calculated according to the equation of Henderson and Titton, 1955).

$$
\begin{gathered}
\text { Treatment after } \times \text { control before } \\
\text { Reduction }=1-\text { Treatment before } \times \text { control after }
\end{gathered}
$$

\section{Statistical analysis:}

One-way analysis of variance (ANOVA) and mean comparison using Fisher's least significant difference (LSD) were conducted for the number of spider mite, using the software packages SPSS 16.0.0 (USA) for windows. Significance level was $\mathrm{P} \leq 0.05$.

\section{Results and Discussion}

Two predatory species (Phytoseiulus persimilis Athias-Henriot and Amblyseius swirskii AthiasHenrio), one biochemical compound Abamectin (Vapcomic) and one chemical compound (Ortus) as well as a control treatment were used to evaluate their effect in reducing the population densities of the two spotted spider mite, Tetranychus urticae Koch on the three different melon cultivars (Shahd, Ananas and Galia) at Behaira Governorate during 2014 season. 
The control experiments were started on the three melon cultivars from the $8^{\text {th }}$ week of germination when the infestation of the melon cultivars with $T$. urticae was started. The average number of spider mite was about the same on the three melon cultivars (about 20 individuals/leaf, on $26^{\text {th }}$ of March then the experiments was started).

The average number of spider mite, $T$. urticae on the three melon cultivars (Shahd, Ananas and Galia) was affected by releasing the two predatory mites and spraying with Vapcomic and Ortus. Figure 1 shows the relation between time (week) and the mean average numbers of the spider mite (individual) for the previously mentioned four treatments as well as the control for each of the three cultivars.

For the Shahd cultivar, in general, the control treatment shows that the number of spider mite population was slightly increasing through the first 6 weeks then the spider mite population started to increase at a high rate at the rest of the experiment intervals.

The effect of Phytoseiulus persimilis on spider mite, T. urticae was crucial compared to the effect of the other three treatments. So, the curve describes spider mite population decreased and reached approximately the zero value through the first five weeks from the beginning of the experiment and the spider mite population kept this value till the end of the season (Figure $1 \mathrm{~A}$ ).

Both the bichomical (Vapcomic) and chemical compound (Ortus) treatment curves had nearly the same trend (Figure $1 \mathrm{~A}$ ), but the chemical treatment had obviously sharper decrease in the spider mite population for the first week from spraying. Then, the number of spider mite population under each of the two treatments had a case of stability for about 5 weeks after that the population number started to increase and this increase continued till the end of the season.

The predatory mite, Amblyseius swirskii treatment had obviously the lowest effect on the spider mite population as its population was the highest under this treatment compared to each of the other three used treatments. Through the first week, the spider mite population curve decreased significantly compared to that of the control. Then the population of the spider mite remained constant for the next 5 weeks after which the population started to increase and this increase continued till the end of the season at which the population reached (62.30 individuals/leaf; Figure 1 A).

The previous discussion for the Shahd cultivar maybe applied to Ananas and Galia cultivars as could be seen from figures $1 \mathrm{~B}$ and $\mathrm{C}$.

Table 1 describes the average number and Table 2 describes the average reduction percentage \pm standard error (SE), maximum and minimum of the spider mite population for each of the four treatments as well as the control on each of the three cultivars.

For the Shahd, there was a significant difference of the average number and average reduction percentage of spider mite $T$. urticae population among the different treatments $\left(F_{4,54}=13.082 ; P<0.05\right.$ and $F_{3,36}=15.65 ; P<0.05$ respectively). The controlling effect of the specialist predatory mite, $P$. persimilis had the highest average number of spider mite population 3.29 individual/leaf, which corresponds to $93.11 \%$ reduction percentage; LSD; $P<0.05$. Next in effect on the spider mite population was both, the chemical compound (Ortus) with 8.93 individual/leaf, with $84.51 \%$ reduction percentage and bichomical (Vapcomic) treatment with 12.45 individual/leaf with $77.80 \%$ reduction percentage and there was no significant difference between these two compounds (LSD; $P>0.05$ ). While the controlling effect of the generalist predatory mite, A. swriskii had the lowest average number of spider mite population 23.34 individual/leaf with $49.31 \%$ reduction with significant difference with other treatments (LSD; $P<0.05$; Tables 1 and 2).

The previous description for the Shahd cultivar maybe applied to Ananas and Galia cultivars as could be seen from Tables 1 and 2 .

Predatory mites in the Acari family: Phytoseiidae, play an important role in the regulation of phytophagous mite populations and consequently reduce the application of acaricides. So the biological control is much more economical than chemical control. The two-spotted mite, T. urticae is phytophagous nature, high reproductive potential and short life cycle rapid resistance development too, many acaricides often after a few applications (Stumpf and Nauen, 2001). Failure in the chemical control of $T$. urticae resistance have been reported in several countries for compounds, such as organophosphates (Sato et al.1994), abamectin (Beers et al., 1998) and fenpyroximate (Stumpf and Nauen, 2001; Sato et al., 2004). To reduce these problems, it is necessary to minimize the chemical control by replacement pesticides by using biocides and releasing predatory mites. Several species of natural enemies have been reported to prey on $T$. urticae and studies have been conducted in different countries to assess the effect and potential of natural enemies for controlling the pest without the use of pesticides without economic damage to the crop (Garcia-Mari and GonzalezZamora, 1999). Amblyseius swirskii is a polyphagous predator capable of preying on a number of spider mites (Swirski et al., 1967). The two predatory mite species showed different effect in reducing the population densities of the two spotted spider mite, $T$. urticae on three different melon cultivars, being higher in effect in reducing the population densities of the two spotted spider mite, T. urticae for P. persimilis treatment than in that for A. swirskii treatment.

The predatory mite, $P$. persimilis gave the lowest population number of spider mite, T. urticae 3.29 individual for Shahd, 4.05 individual for Ananas and 3.60 individual/ leaf for Galia. The predatory mite, $P$. 
persimilis was good at driving spider mite population to extinction. These results agree with (Gould, 1971; Abdallah et al., 2015), Phytoseiulus persimilis type I as a specialist predator of all species of genus Tetranychus (McMurtry and Croft, 1997); and could provide the best control of this pest, T. urticae.

\section{(A) ShahdA}

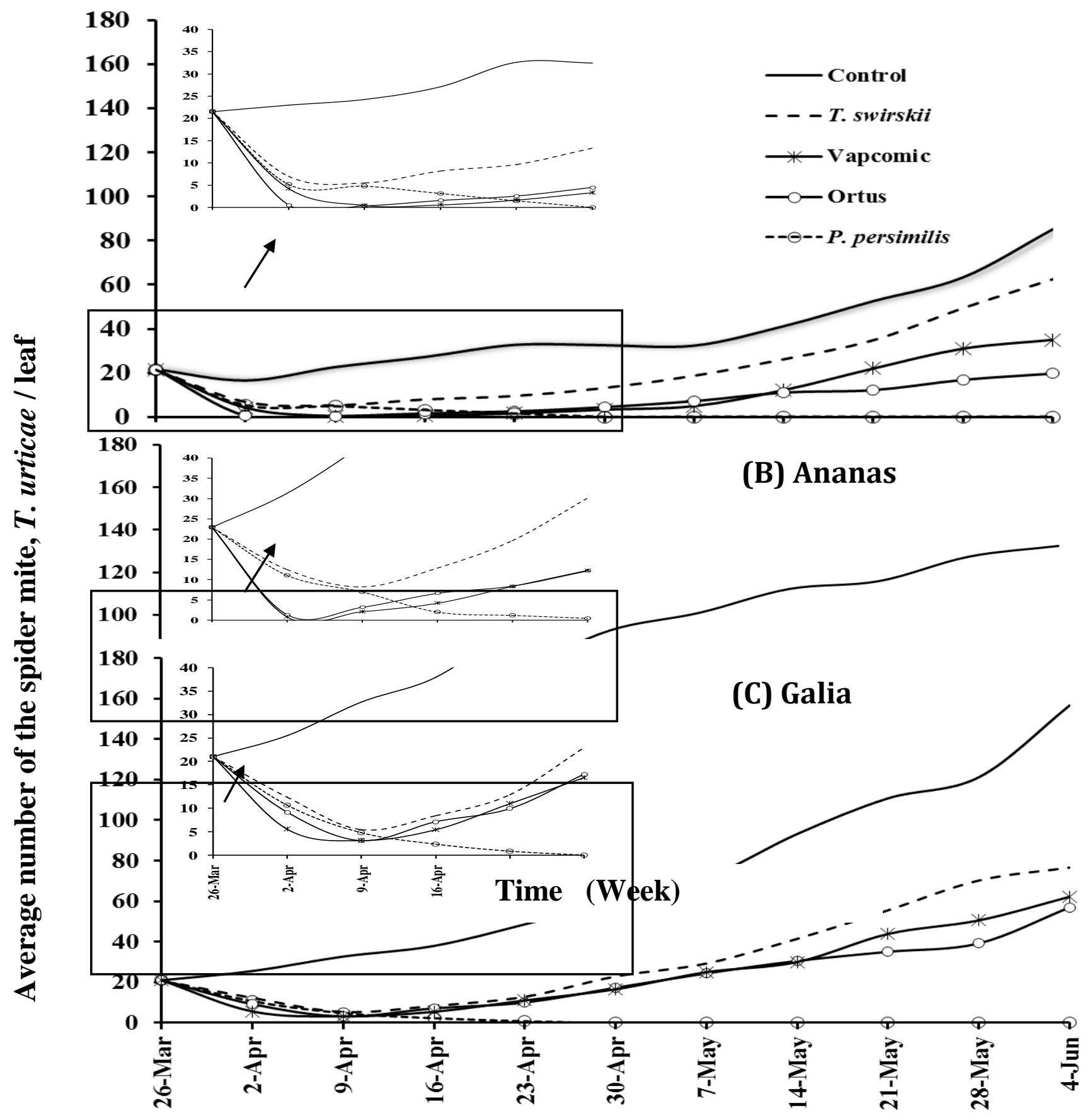

Figure 1: The average number of the spider mite, T. urticae / leaf, weekly on the three melon cultivars \{(A) Shahd, (B) Ananas and (C) Galia)\} affected by releasing the two predatory mite species and spraying with Vapcomic and Ortus as well as the control. 
Table 1. The population average numbers of spider mite, $T$. urticae / leaf on the three melon cultivars affected by releasing the two predatory mite species and spraying with Vapcomic and Ortus as well as the control.

\begin{tabular}{|c|c|c|c|c|c|c|c|c|c|c|}
\hline \multirow{3}{*}{ Treatments } & \multicolumn{9}{|c|}{ Melon cultivars } & \multirow{3}{*}{$\begin{array}{c}\text { Overall } \\
\text { mean }\end{array}$} \\
\hline & \multicolumn{3}{|c|}{ Shahd } & \multicolumn{3}{|c|}{ Ananas } & \multicolumn{3}{|c|}{ Galia } & \\
\hline & Mean $\pm \mathrm{SE}$ & Max. & Min. & Mean $\pm \mathrm{SE}$ & Max. & Min. & Mean \pm SE & Max. & Min. & \\
\hline$P$. persimilis & $3.29 \pm 2.02 \mathrm{a}$ & 21.55 & 0.00 & $4.05 \pm 2.28 \mathrm{a}$ & 22.90 & 0.00 & $3.60 \pm 2.10 \mathrm{a}$ & 21.00 & 0.00 & $3.65 \mathrm{a}$ \\
\hline A. swirskii & $23.34 \pm 5.88_{c}$ & 62.30 & 5.50 & $36.75 \pm 8.00_{c}$ & 81.80 & 8.25 & $32.48 \pm 7.96 b$ & 76.75 & 5.50 & 30.86 c \\
\hline Ortus & $8.93 \pm 2.48_{b}$ & 21.55 & 0.40 & $20.76 \pm 5.26 b$ & 50.80 & 1.35 & $23.09 \pm 5.16 b$ & 56.95 & 3.15 & $17.59_{b}$ \\
\hline Vapcomic & $12.45 \pm 4.04_{b}$ & 35.00 & 0.45 & $23.93 \pm 6.70_{b c}$ & 63.00 & 0.80 & $24.95 \pm 6.27_{b}$ & 62.20 & 3.15 & $20.44_{b}$ \\
\hline Control & $38.85 \pm 6.53 d$ & 85.20 & 16.45 & $82.72 \pm 12.41_{d}$ & 132.45 & 22.90 & $70.87 \pm 14.03 c$ & 156.65 & 21.00 & $64.15_{d}$ \\
\hline Overall mean & $17.37_{\mathrm{A}}$ & - & - & $33.64_{\text {B }}$ & - & - & $31.00_{\text {B }}$ & - & - & - \\
\hline
\end{tabular}

Means followed by different subscript letters within columns are significantly different from each other $(\mathrm{P}<0.05)$ LSD test

Overall mean followed by different subscript capital letters within row is significantly different from each other $(\mathrm{P}<0.05)$ LSD test 


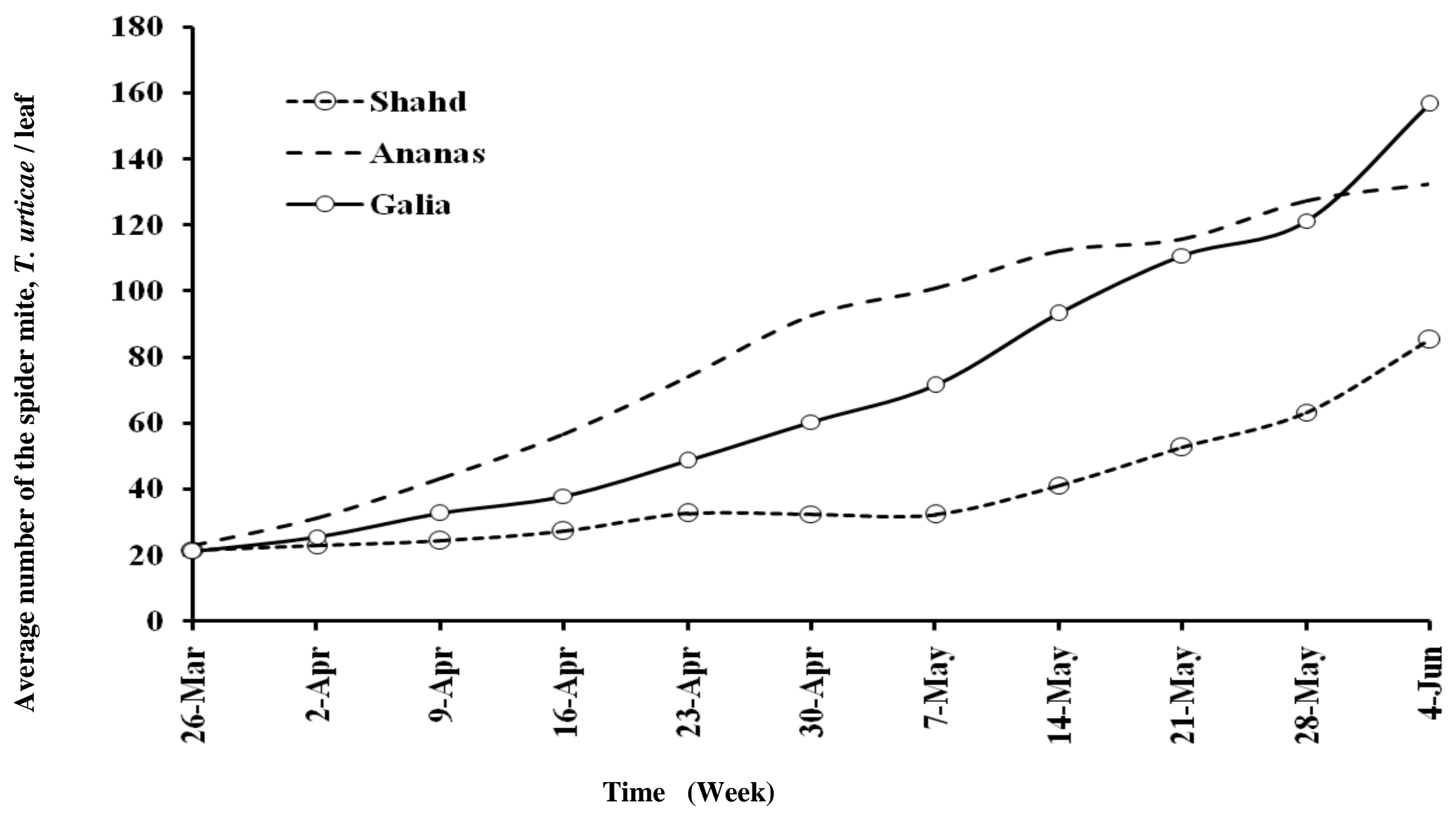

Figure 2: The average number of the spider mite, T. urticae /leaf, weekly on the control of the three plant species. 
Table 2. The population average numbers of spider mite, T. urticae / leaf and their corresponding reduction percentage (\%) by the two predatory mite species, Vapcomic and Ortus on the three melon cultivars.

\begin{tabular}{|c|c|c|c|c|c|c|c|c|c|c|}
\hline \multirow{3}{*}{ Treatments } & \multicolumn{9}{|c|}{ Reduction \% of each cultivar } & \multirow{3}{*}{$\begin{array}{c}* \text { Overal } \\
\text { mean }\end{array}$} \\
\hline & \multicolumn{3}{|c|}{ Shahd } & \multicolumn{3}{|c|}{ Ananas } & \multicolumn{3}{|c|}{ Galia } & \\
\hline & Mean $\pm \mathrm{SE}$ & Max. & Min. & Mean $\pm \mathrm{SE}$ & Max. & Min. & Mean \pm SE & Max. & Min. & \\
\hline P. persimilis & $93.11 \pm 3.54 a$ & 100.00 & 68.39 & $94.31 \pm 3.64 a$ & 100.00 & 64.75 & $93.57 \pm 4.19 a$ & 100.00 & 58.32 & $93.66_{A}$ \\
\hline A. swirskii & $49.31 \pm 6.18 \mathrm{c}$ & 75.61 & 22.18 & $61.04 \pm 4.56 c$ & 80.95 & 38.24 & $60.43 \pm 4.27 c$ & 83.18 & 41.91 & $56.93 \mathrm{C}$ \\
\hline Ortus & $84.51 \pm 3.18_{b}$ & 98.23 & 73.03 & $80.80 \pm 3.72_{b}$ & 95.69 & 61.65 & $71.91 \pm 2.79_{b}$ & 90.37 & 63.65 & 79.07 \\
\hline Vapcomic & $77.80 \pm 5.59 b$ & 98.00 & 51.07 & $78.42 \pm 5.08_{b}$ & 97.45 & 52.43 & $71.58 \pm 3.51_{b}$ & 90.37 & 58.29 & $75.94_{B}$ \\
\hline Control & - & - & - & - & - & - & - & - & - & - \\
\hline
\end{tabular}


The three control treatments

For the three control treatments, there was a significant difference of the average number of spider mite population in case of the three melon cultivars $\left(F_{2,30}=4.31 ; P<0.05\right.$ table 1$)$. There was a significance difference between shahd control treatment and each of Ananas and Galia (LSD; $P<0.05$ table 1 ), while there was no significant difference between Ananas and Galia (LSD; $P<0.05$ table 1 ).

Figure 2 shows the relation between time (week) and the mean average numbers of the spider mite (individual) for the control of the three cultivars (). Figure 2 indicates that the least infestation with spider mite, T. urticae was in case of Shahd cultivar. The average number of spider mite population was 38.85 individual in case of Shahd cultivar while the average number in case of each of Ananas and Galia cultivar was 82.72 and 70.87 individual, respectively (Table 1).

\section{Conclusion}

The Shahd cultivar was relatively much tolerance to the spider mite $T$. urticae infestation than another tested cultivar, using the predatory mite, $P$. persimilis gave the highest population reduction of spider mite, $T$. urticae among the four tested treatments, also it is more preferable for controlling the spider mite, $T$. urticae, and controlling the spider mite using the biochemical compound (Vapcomic) is much preferable than using the chemical compound (Ortus) as there was no significant difference was found between them.

\section{References}

Abdallah, A.A.; Abbassy, M.R.A and Salem, A.A. 2015. Efficacy of two essential oil extracts and predatory mite Phytoseiulus persimilis in suppressing the population of the two-spotted spider mite, Tetranychus urticae Koch. J. Plant Prot. And Path., Mansoura Univ., Vol. 6 (7): 11411151.

Beers, E.H.; Riedl, H. and Dunley, J.E. 1998. Resistance to abamectin and reversion to susceptible fenbutatin oxide in spider mite (Acari: Tetranychidae) populations in the Pacific Northwest. J. Econ. Entomol., 91: 352-360.

Cho, J.R.; Hong, K.J.; Choi, B.R.; Lee, G.S.; Lee, G.S., Yoo, J.K. and Lee, J.O. 1995. The inhibition effect of the twospotted spider mite population density by using the introduced predacious mite (Phytoseiulus persimilis Athias-Henriot) and effect of several pesticides to the predacious mites. RDA. J. Agric. Sci., 37: 340-347.

El-saiedy, E.M.A. 2003. Integrated control of red spider mite Tetranychus urticae Koch on strawberry plants. Ph.D. Thesis, Fac. Agri., Cairo
Univ., PP: 171

Garcia-Mari, F. and Gonzalez-Zamora, J.E. 1999. Biological control of Tetranychus urticae (Acari: Tetranychidae) with naturally occurring predators in strawberry plantings in Valencia, Spain. Exp. Appl. Acarol. 23: 487-495.

Gould, H.J. 1971. Large-scale trials of an integrated control program for cucumber pests on commercial nurseries. Plant Path. 20:149-156.

Helle, W. and Sabelis, M.W. 1985. Spider mites. Their biology, natural enemies and control. Volume (1): 75- 90 pp. Elsevier, New York.

Henderson, C.E. and Tilton, E.W. 1955. Tests with acaricides against the brown wheat mites. J. Econ. Entomol., 84: 157-161.

Hussey, N.W. and Huffaker, C.B. 1976. Spider mites. In: Delucchi VL (ed) Studies in biological control. Cambridge University Press, London, pp 179-228.

McMurtry, J.A. and Scriven, G.J. 1965. Insectory production of Phytoseiulus persmilis. J. Econ. Entomol., 58, 282- 284.

McMurtry, J.A., and Croft, B.A. 1997. Life styles of phytoseiid mites and their roles in biological control. Ann. Rev. Entomol. 42:291-321.

Nayar, N.M., and Singh, R. 1998. Taxonomy, distribution and ethnobotanical uses in Cucurbits (N.M. Nayar, and T.A. More, eds.). Science Publishers, Inc., U.S.A. pp 1-18.

Ragusa, S. and Swirski, E. 1975. Feeding habits, development and oviposition of the predacious mite Amblyseius swirskii Athias-Henriot (Acarina: Phytoseiidae) on pollen of certain weeds. Israel Journal of Entomology 10: 93-103.

Sato, M.E.; Suplicy Filho, N.; de Souza Filho, M.F. and Takematsu, A.P. 1994. Resistencia do acaro rajado Tetranychus urticae (Koch, 1836) (Acari: Tetranychidae) a diversos acaricidas em morangueiro (Fragaria sp) nos municipios de Atibaia- Sp e Piedade-Sp. Ecossistema, 19: 40-46.

Sato, M.E.; Miyata, T.; da Silva, M.; Raga, A. and de Souza Filho, M.F. 2004. Selections for fenpyroximate resistance and susceptibility, and inheritance, cross-resistance and stability of fenpyroximate resistance of Tetranychus urticae Koch, (Acari: Tetranychidae). Appl. Entomol. Zool., 39: 293-302.

Schausberger, P. 1991. Vergleichende Untersuchungen zum Lebensverlauf, die Erstellung von Lebenstafeln und die Vermehrungskapazität von Amblyseius aberrans Oud. und Amblyseius finlandicus Oud. (Acari: Phytoseiidae). Pflanzenschutzber 52: 53-71.

Stumpf, N. and Nauen, R. 2001. Cross-resistance, inheritance, and biochemistry of mitochondrial electron transport inhibitor- acaricide resistance in Tetranychus urticae (Acari: Tetranychidae). J. Econ. Entomol., 94: 1577-1583.

Swirski, E.; Amitai, S. and Dorzia, N. 1967. La- 
boratory studies on the feeding, development and reproduction of the predacious mites Amblyseius rubini Swirski and Amitai and Amblyseius swirskii Athias (Acarina: Phytoseiidae) on various kinds of food substances. Israel J. Agric. Res., 17: $101-119$.

van de Vrie, J.A.C.; McMurtry, J.A. and Huffaker, C.B. 1972. Ecology of mites and their natural enemies. A review. III Biology, ecology, and pest status, and host plant relations of tetranychids. Hilgardia, 41: 354-432.

van Houten, Y.M.; Ostilie, M.L.; Hoogerbrugge, H. and Bolckmans, K. 2005. Biological control of western flower thrips on sweet pepper using the predatory mites Amblyseius cucumeris,
Iphiseius degenerans, A. andersoni and A. swirskii. IOBC/wprs Bulletin 28(1): 283-286.

van Leeuwen, T.; Vontas, J.; Tsagkarakou, A.; Dermauw, W. and Tirry, L. 2010. Vapcomic resistance mechanisms in the two spotted spider mite Tetranychus urticae and other important Acari; a review. Mol. Biol. 40:563-572.

Yadav, R.C.; Salah, M.T. and Grumet, R. 1996. High frequency shoot regeneration from leaf explant of muskmelon. Plant Cell Tissue and Organ Culture 45: 207-214.

Zhang, Z.Q. 2003. Mites of Greenhouses. Identification, biology and control. CABI Publishing Oxon, UK. 244 pp. 
مكافحة الأكاروس العنكبوت الأحمر Tetranychus urticae Koch على ثلاث اصناف من الشمام

\author{
عوض على عبدالله \\ قسم الحيوان الزراعى وإلنيماتودا - كلية الزراعة - جامعة الازهر بالقاهرة
}

تم دراسة تاثير نوعين من المفترسات الاكاروسية الـ Phytoseiulus persimilis والـ Amblyseius swirskii

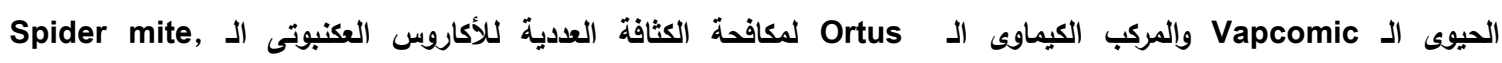
Tetranychus urticae

2014

يوجد اختلافَ معنوى فى متوسط نسبة خفضِ تعداد الأكاروس العنكبوتِى بين المعاملات المختلفة، حيث كانت علي الـ Shahd

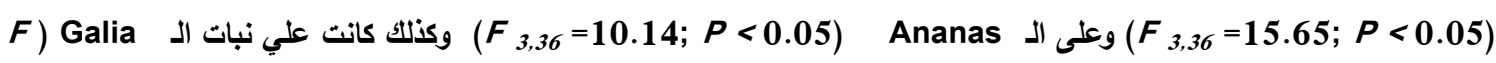
3.36=13.75; $P<0.05$

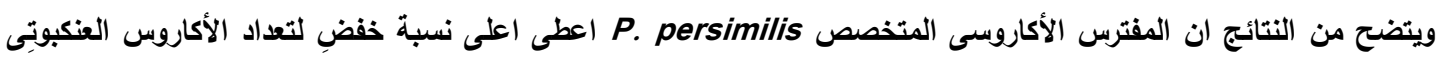
على الثلاثة اصناف من الثمام بنسبة خفض (93.66\%).

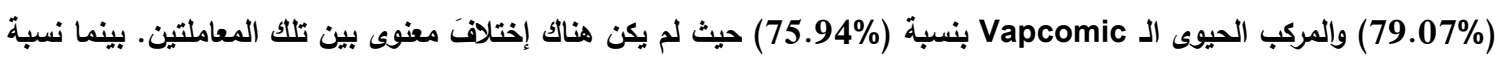
الخفضِ المئويةِ لتعداد الأكاروس العنكبوتى بالمفترس العام الأكاروسى swirskii

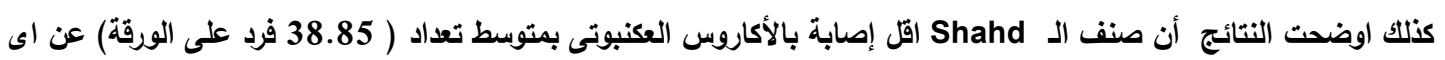

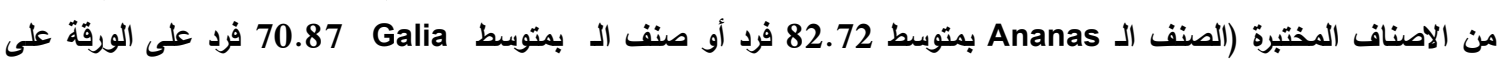

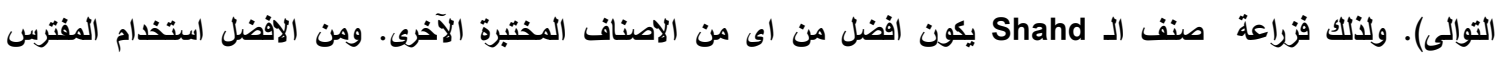

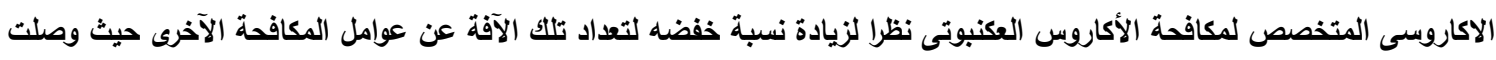
نسبة خفضه بمتوسط 93.66\% على اصناف الثمام الثثلاثة. 